\title{
Current Fertilization Practice and Phosphorus Loading from Soils near Alpine Lakes of Yunnan Province, China
}

\author{
Ling Zou', Kim Falinski2,3, Peifei Zhao', Shenchong Li' ${ }^{1}$, Lin Lu', Min Dai', Yiping Zhang1, \\ Russell Yost ${ }^{5}$, Jihua Wang ${ }^{*}$
}

\author{
${ }^{1}$ Flower Research Institute, Yunnan Academy of Agricultural Sciences, National Engineering Research Center for Ornamental \\ Horticulture, Kunming, China \\ ${ }^{2}$ The Nature Conservancy, Honolulu, HI, USA \\ ${ }^{3}$ Water Resources Research Center, University of Hawaii at Manoa, Honolulu, HI, USA \\ ${ }^{4}$ Yunnan Meteorological Service, Kunming, China \\ ${ }^{5}$ Department of Tropical Plant and Soil Sciences, University of Hawaii at Manoa, Honolulu, HI, USA \\ Email: *wjh0505@gmail.com
}

How to cite this paper: Zou, L., Falinski, K., Zhao, P.F., Li, S.C., Lu, L., Dai, M., Zhang, Y.P., Yost, R. and Wang, J.H. (2019) Current Fertilization Practice and Phosphorus Loading from Soils near Alpine Lakes of Yunnan Province, China. Agricultural Sciences, 10, 1-16.

https://doi.org/10.4236/as.2019.101001

Received: November 27, 2018

Accepted: January 1, 2019

Published: January 4, 2019

Copyright $\odot 2019$ by author(s) and Scientific Research Publishing Inc. This work is licensed under the Creative Commons Attribution International License (CC BY 4.0).

http://creativecommons.org/licenses/by/4.0/

c) (i) Open Access

\begin{abstract}
Phosphorus loss from fertilization is a significant source of pollution to freshwater lakes worldwide. Production of flowers, vegetables, staple food and vineyard in regions surrounding Dianchi, Erhai, Fuxian and Xingyun lakes in Yunnan Province is large-scale. Previous studies have shown that annual fertilizer application rates (AFARs) were excessive in these regions. Significant amount of arable land near lakes has been used to build recreational parks with plants that receive less fertilization to reduce $\mathrm{P}$ loading. To answer whether rAFARs were associated with specific crops, AFARs of specific land uses were investigated through interviews. To estimate $\mathrm{P}$ loading, $\mathrm{NaHCO}_{3}-\mathrm{P}$ and $\mathrm{NaOH}-\mathrm{P}$ concentrations were measured in 753 soil samples of selected layers $(0-5,5-20,20-40 \mathrm{~cm})$ in regions surrounding these lakes. Soil texture, $\mathrm{pH}$, and cation exchange capacity (CEC) were analyzed to characterize soils. P loading was high ranging from 999 to $2094 \mathrm{mg} \mathrm{P} / \mathrm{kg}$ as measured by $\mathrm{NaOH}-\mathrm{P}$, and levels of $\mathrm{NaHCO}_{3}-\mathrm{P}$ from 18.6 to $92.2 \mathrm{mg} \mathrm{P} / \mathrm{kg}$. AFARs to flower $(4745 \mathrm{~kg} / \mathrm{ha})$, and vegetable $(2967 \mathrm{~kg} / \mathrm{ha})$ were higher than those applied to staple food $(945 \mathrm{~kg} / \mathrm{ha})$, and plants in recreation parks $(200 \mathrm{~kg} / \mathrm{ha})$. The highest $\mathrm{NaHCO}_{3}-\mathrm{P}$ and $\mathrm{NaOH}-\mathrm{P}$ concentrations in selected layers were associated with production of flowers, vegetables, and grapes. Although all layers of soils that were used for recreation parks in regions near Dianchi lake contained lower $\mathrm{NaHCO}_{3}-\mathrm{P}, \mathrm{NaOH}-\mathrm{P}$ was almost as high as with soils cultivated with flowers probably reflecting historical additions or differences in
\end{abstract}


soil type. Here we show for the first time in local regions that the production of flowers, grapes and vegetables was a critical source contributing to the buildup of both readily available $\left(\mathrm{NaHCO}_{3}-\mathrm{P}\right)$ and reversibly available $\mathrm{P}$ (NaOH-P). Build-up of recreational parks with plants that receive less fertilization would be a long-term remediation to reduce $\mathrm{P}$ loading of soils in regions near Dianchi lake.

\section{Keywords}

Fertilization, Phosphorus, Crop, Lake

\section{Introduction}

Anthropogenic nutrient loading is a problem that affects the water quality of freshwater lakes and the provisioning of drinking water worldwide. Freshwater systems exposed to eutrophication require significant nutrient management in order to restore water quality for human and habitat use. Globally, the export of bioavailable phosphorus is of increasing concern due to its adverse impact on freshwater water quality. Phosphorus, in particular, persists in a labile form through various degrees of adsorption to soil inorganic surfaces. Phosphorus is often a limiting factor for phytoplankton and aquatic plant growth in lakes [1]. Phosphorus input from agricultural practices can be limited through improved nutrient management programs.

Fertilizers contribute substantially to the global anthropogenic P load into streams and lakes [2]. Applied $\mathrm{P}$ designed to be plant-available is, therefore, more likely to be exported [3]. Guo and Yost (1998) characterize the various fractions in soil into "readily plant-available" and "reversibly plant-available" and "sparingly available" forms based on plant uptake data. In Yunnan province in southwest China, inland alpine lakes have supported the local people for thousands of years by providing irrigation water, drinking water, farming, fisheries, flood protection and recreation. However, in the last 70 years there has been a conversion from oligotrophic to nearly entirely eutrophic aquatic systems due to deforestation, agricultural inputs and wastewater contributions [4]. Recent estimates suggest that the lakes on the Yunnan plateau are some of the most polluted in China [5]. The water quality of Dianchi lake is categorized as heavily polluted; algae blooms have taken place every year in the last two decades. The average values of total nitrogen $(\mathrm{N})$ and total phosphorus $(\mathrm{P})$ of Dianchi lake are respectively, $6.5 \mathrm{mg} / \mathrm{L}$ and $0.17 \mathrm{mg} / \mathrm{L}$ [6], of Erhai lake, $0.48 \mathrm{mg} / \mathrm{L}$ and $0.04 \mathrm{mg} / \mathrm{L}$ [6], and of Fuxian lake $0.15 \mathrm{mg} / \mathrm{L}$ and $0.007 \mathrm{mg} / \mathrm{L}$ [4].

Approximately $45 \%$ of the total P inputs to Dianchi lake are reported to be sourced from agricultural land uses [5], which, therefore, presents an opportunity to reduce the overall $\mathrm{P}$ input into the lake through appropriate land and nutrient management strategies [7]. However, in order for producers and land use managers to make recommendations on how to optimize $\mathrm{P}$ fertilizer rates, they 
need to know for which crops fertilizer needs are most misaligned with current fertilizer rates as well as the properties of the soils to which the fertilizer is applied. Determination of fertilizer rates for specific land uses has been lacking for this region. Plant availability of input $\mathrm{P}$ as well as release of $\mathrm{P}$ depends on soil properties [8] [9]. However, there apparently is little information available on the underlying soil characteristics regarding $\mathrm{P}$ sorption and subsequent plant availability that can be used to guide fertilizer application rate.

Excessive use of chemical fertilizers is common in regions surrounding Dianchi lake, Erhailake, and Fuxian lake (Figure 1). These are the three largest lakes in Yunnan province. A survey conducted in 2012 reported that in the northeast of Dianchi lake, chemical fertilizer application rates ranged from 1800 to $7500 \mathrm{~kg} / \mathrm{ha}$ for selected landowners [10]. In regions surrounding Fuxian lake, on the average, the chemical fertilizer application rates were as high as $3900 \mathrm{~kg} / \mathrm{ha}$ in 2002; to the north of Erhai lake, in 2010, the chemical fertilizer application rates ranged from 250 to $1100 \mathrm{~kg} / \mathrm{ha}$ [11].

The area of arable land is decreasing because of urbanization, leading to agricultural land conversion to diversified agriculture, specialty crops and floriculture. Specifically, there was a recent shift from cultivating staple food crops such as rice and maize to cultivating crops such as flowers, vegetables and other crops with higher profits for producers. Previous studies have shown that specific land uses, field management techniques, fertilizer application rates and plant species were factors that increase variability of $P$ concentrations in soils [3] [12]. In the last two decades, because of the concern on the degrading water quality, in regions around these lakes, significant amount of arable land has been used to build recreational parks with bush, tree and herbaceous perennials that receive much less fertilization.

To provide more accurate soils information to characterize and assess current $\mathrm{P}$ fertilizer application rates and to suggest ways to limit further $\mathrm{P}$ related pollution, this study analyzed the relationships between soil P concentration, land use, crop types and soil properties for four lakes on the Yunnan plateau. The questions addressed in this paper were as follows: 1) is the excessive fertilization related to specific crops? 2) how does excess fertilization influence $P$ concentrations in different layers of soils? And 3) what are some options for reducing $\mathrm{P}$ export to the lakes caused by excessive levels of fertilization and the high levels of soil P? This study investigated these questions in order to identify best management practices and field management that could help reduce excessive levels of $\mathrm{P}$ in the associated lakes and water bodies. By analyzing $\mathrm{P}$ concentrations in soils of recreation parks with plants that receive less fertilization, we aim to evaluate the effect of less fertilization in reducing $\mathrm{P}$ loading.

\section{Materials and Methods}

\subsection{Site Description}

Dianchi lake, Erhai lake, Fuxian lake, Xingyun lake, and the region east to Yangzong lake and Nanpan river are situated in the east of Yunnan province; 


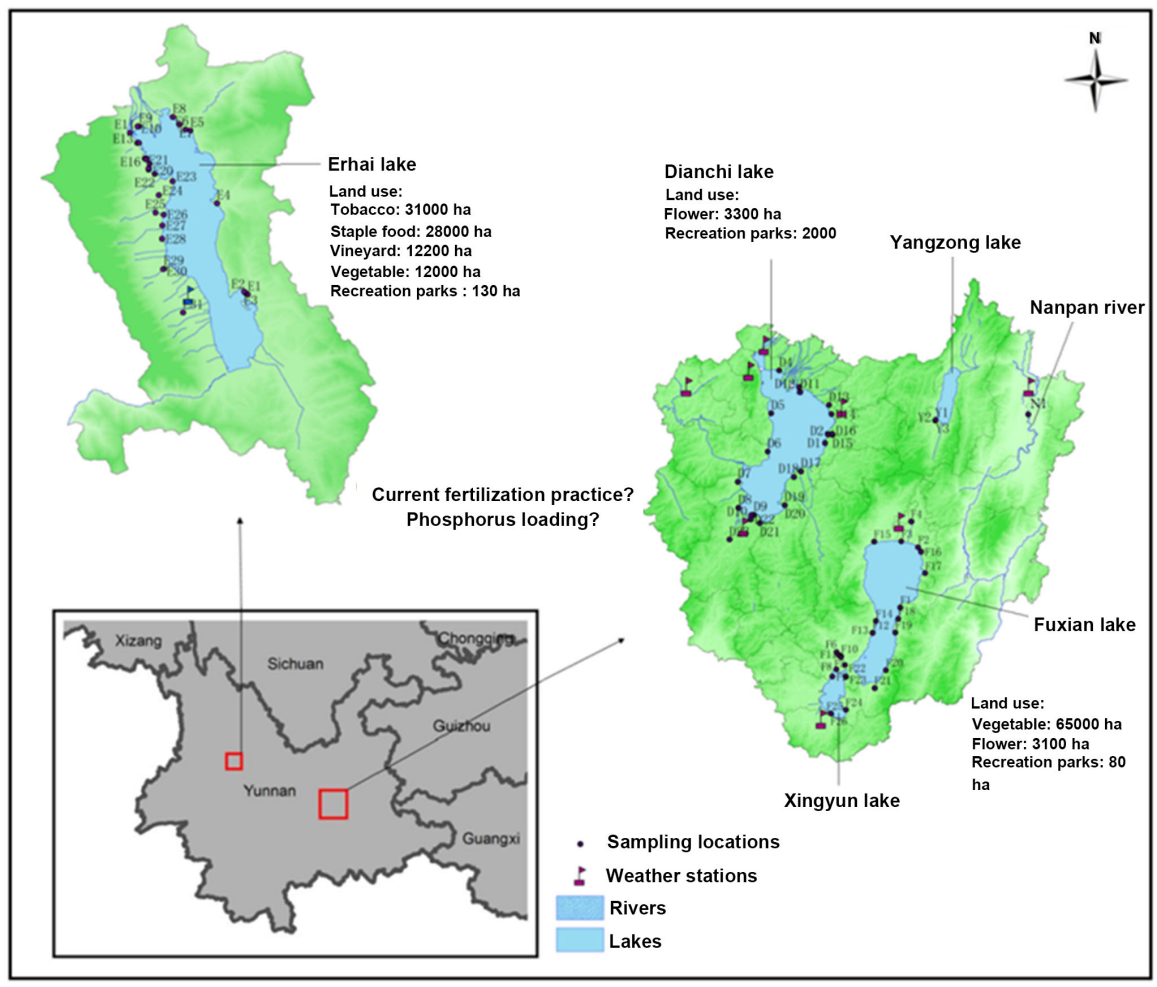

Figure 1. Dianchilake, Erhai lake, Fuxian lake, Xingyun lake, Yangzong lake and Nanpan river in Yunnan Province, China. Soil samples surrounding lakes were taken in locations represented by black solid circles in the figure.

while Erhai lake is located in the Northwest (Figure 1). The elevation of the region surrounding Dianchi lake is about $1880 \mathrm{~m}$ compared to $1730 \mathrm{~m}$ for Fuxian lake and Xingyun lake, 1970 m, further west, for Erhai lake, $1770 \mathrm{~m}$ for Yangzong lake, and $1530 \mathrm{~m}$ for Nanpan river. Annual rainfall in regions near Dianchi lake was $840 \mathrm{~mm}$, Erhai lake $1036 \mathrm{~mm}$, Fuxian and Xingyun lakes $854 \mathrm{~mm}$, Yangzong lake $858 \mathrm{~mm}$, and Nanpan river $847 \mathrm{~mm}$ [annual rainfall in the selected regions surrounding lakes and near the river was a 30-year (1986-2015) average obtained from the Department of Meteorology, Yunnan Province]. The volume of Dianchi lake is 1.4 billion $\cdot \mathrm{m}^{3}$, Erhai lake $2.8 \mathrm{billion} \cdot \mathrm{m}^{3}$, Fuxian lake 18.8 billion $\cdot \mathrm{m}^{3}$, Xingyun lake $0.2 \mathrm{billion} \cdot \mathrm{m}^{3}$, Yangzong lake $0.6 \mathrm{billion} \cdot \mathrm{m}^{3}$.

\subsection{Interviews}

A focus group comprised of officers of the departments of agriculture in each local government was asked to describe the most economically important crops in regions near the lakes and the river. In regions near Dianchi lake, flower [carnation (Dianthus sp.), Lisianthus flower (Eustoma sp.), baby's-breath (Gypsophila sp.), and rose flower (Rosa sp.)] production covers about 3300 ha, and recreation parks (cultivated with herbaceous perennials and bush), 2000 ha. In regions near Fuxian and Xingyun lakes, flower production covers about 3100 ha, vegetables [coriander (Coriandrum sativum), garlic (Allium sativum), pepper (Capsicum sp.), and tomato (Solanum lycopersicum)], 65,000 ha, recreation 
parks, 80 ha. In regions near Erhai lake, staple food [maize (Zea mays), rice (oryza sativa), taro (Colocasia esculenta)] covers about 28000 ha, recreation parks, 130 ha, vegetables, 12,000 ha, Tobacco (Nicotiana sp.), 31,000 ha, vineyard, 12,200 ha. Due to the climate in these regions being sub-tropical; crops can be grown across the whole year.

We conducted interviews between June and August 2016 in order to obtain estimates of annual fertilizer application rate (AFAR) in farms surrounding the selected lakes (Figure 1). The farms included in this project's sampling were selected because they had consistently maintained crop production practices for at least two years prior to the study. The number of farms that meet this criterion was 84 . Producers were asked the following questions: 1) How many years have they applied or used the same crop and field management? And 2) what is the average annual fertilizer application rate for one $m u$ (One $m u$ is the unit of land measure in China (approximately $666 \mathrm{~m}^{2}$ ). Forty two out of 84 producers did not quantify or did not answer the second question and were not included in the estimates of fertilizer application rate reported in this manuscript.

\subsection{Soil Sample Analysis ( $\mathrm{NaHCO}_{3}-\mathrm{P}$ and $\left.\mathrm{NaOH}-\mathrm{P}\right)$}

In order to quantify and understand the effect of crop, lake location, and soil properties on $\mathrm{P}$ concentration, we collected 753 soil samples from 84 sites collocated with farms. Samples were collected avoiding the edges of the farm plots in order to be representative. At each site three replicate soil samples were randomly collected from three layers, namely, A $(0-5 \mathrm{~cm}), B(5-20 \mathrm{~cm}), \mathrm{C}$ $(20-40 \mathrm{~cm})$. At location D10, samples of layer $\mathrm{C}$ were not taken, because the soil was too shallow. In total, there were 234 soils samples from flower production, 18 from orchard, 177 from recreation parks, 117 from staple food, 18 from strawberry, 36 from tobacco, 9 from tree plantation, 117 from vegetables, 27 from vineyard.

These three depths were chosen based on the following 1) Due to concern about soil-derived P entering the surface runoff, we sampled the $0-5 \mathrm{~cm}$ zone, which is the zone in direct contact with surface runoff. 2) The $5-20 \mathrm{~cm}$ zone, being the likely crop rooting zone, is usually tilled, fertilized and is thus the zone that provides the majority of the nutrients to the various crops. 3) The $20-40 \mathrm{~cm}$ zone is usually below the zone of tillage and direct fertilizer application and incorporation and thus likely represents the historical, long-term $\mathrm{P}$ status reflecting the dynamics of soil development as well as an indication of possible deeper leaching of fertilizer $P$.

Prior to analyses, we air-dried and homogenized all soil samples, and sieved each through a 2-mm mesh. Following recommendations from Guo and Yost (1998) and considering that the soils were generally of $\mathrm{pH}$ less than 7, we determined $\mathrm{NaHCO}_{3}-\mathrm{P}$ as a measure of "readily available $\mathrm{P}$ " and $\mathrm{NaOH}$ as a measure of "reversibly available P". We chose to use the Page (1965) procedure, which recommends $0.5 \mathrm{M} \mathrm{NaOH}$ rather than the $0.1 \mathrm{M} \mathrm{NaOH}$ method suggested by Hedley, et al. [13] in order to more completely extract this fraction of P. Samples 
for $\mathrm{NaHCO}_{3}-\mathrm{P}$ analysis were prepared from $2.5 \mathrm{~g}$ of soil with $50 \mathrm{~mL}$ of $0.5 \mathrm{M}$ $\mathrm{NaHCO}_{3}$ solution ( $\mathrm{pH}$ 8.5) for $30 \mathrm{~min}$ [14]. Phosphorus concentrations were determined by UV-VIS spectrophotometer 752 (APL Instruments Shanghai Co., Ltd., Shanghai, China).

\subsection{Determination of pH, Cation Exchange Capacity (CEC) and Soil Texture}

Soil samples of layers A $(0-5 \mathrm{~cm}), \mathrm{B}(5-20 \mathrm{~cm}), \mathrm{C}(20-40 \mathrm{~cm})$ for each replicate were pooled and homogenized. CEC was determined by titrating the distillate with $0.025 \mathrm{M} \mathrm{HCl}$ from $5 \mathrm{~g}$ soil saturated by $1 \mathrm{M} \mathrm{CH}_{3} \mathrm{COONH}_{4}$ with $\mathrm{pH}$ adjusted to 7 [15]. Soil $\mathrm{pH}$ was measured in deionized water with a soil to water ratio of 1:2.5 by a glass electrode (Mettler-Toledo Inc. Greifensee, Switzerland). Soil texture was determined by the pipette method following the protocol according to [16]. Based on determined proportions of sand, silt and clay, texture classes of soils were categorized using soil texture calculator (NRCS, USDA).

\subsection{Data Analyses}

Statistical analyses were conducted using R. Mean values of AFARs on each crop type were calculated, and standard error was calculated. Dependent variables $\mathrm{NaHCO}_{3}-\mathrm{P}$, and $\mathrm{NaOH}-\mathrm{P}$ of the three layers in soils; $\mathrm{CEC}, \mathrm{pH}$, sand, silt and clay of a composite of the three layers were natural-log transformed to normalize the data for analysis of variance (ANOVA). The values presented in figures were back transformed for readability. We tested the effects of replicates as a random factor on dependent variables, and determined effects of the following fixed factors: region surrounding the lake, land use, crop types, and location on dependent variables using ANOVA. We considered effects statistically significant when $\mathrm{P}<0.05$. Post hoc analyses were conducted using Fisher's least significant difference (LSD) in the "agricolae" package. Correlation analyses (Pearson) using the means between concentrations of $\mathrm{NaOH}-\mathrm{P}$ and $\mathrm{NaHCO}_{3}-\mathrm{P}$ were conducted. Correlations were considered statistically significant when $\mathrm{P}<0.05$. Data of dependent variables of Nanpan River and Yangzong lake were not subjected to correlation analysis because of too few observations.

\section{Results and Discussion}

\subsection{High Annual Fertilization Application Rates (AFAR) Were Associated with Production of Flower, Strawberry and Vegetables}

Annual fertilization application rates (AFARs) for crop production in regions near water bodies of these lakes and the river were the highest for flower, strawberry and vegetable production. All producers reported adopting split application of fertilizers during the growing season; they usually apply N-P-K fertilizers at vegetative stages of crops, and mainly potassium $(\mathrm{K})$ when plants are about to flower. Producers reported the total amount of chemical fertilizers they used annually for all fertilizer types or grades. AFARs in all regions (Figure 2) were 

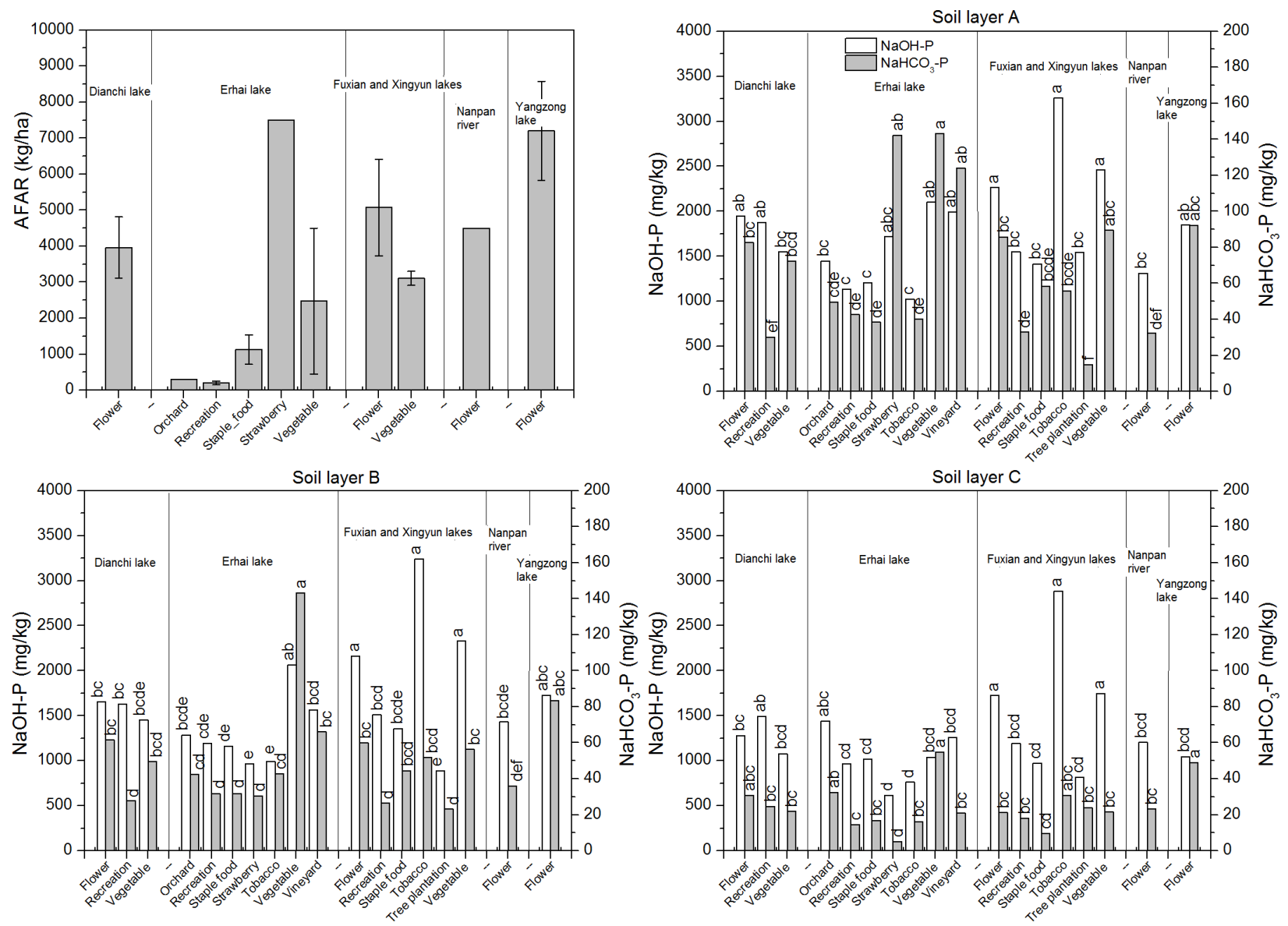

Figure 2. Annual fertilizer application rates (AFAR) of different land uses in regions near lakes and the river (42 out of 84 producers reported AFAR), error bars are $2 \times$ Standard Error, In these regions, the ratios of N:P:K of composite fertilizers are mostly 11:11:11 and 17:17:17. NaOH-P, $\mathrm{NaHCO}_{3}-\mathrm{P}$ concentrations under different land uses in layer A $(0-5 \mathrm{~cm}), \mathrm{B}(5-20 \mathrm{~cm}), \mathrm{C}(20-$ $40 \mathrm{~cm}$ ) of soils in regions near lakes and Nanpanriver. Bars with same letters are not significantly different based on L.S.D. test (P $<95 \%)$.

higher for flower production, ranging from $4000-7500 \mathrm{~kg} / \mathrm{ha}$, compared with vegetable fertilizer application rates were between $2500-3000 \mathrm{~kg} / \mathrm{ha}$. One producer near Erhai lake reported using $7500 \mathrm{~kg} / \mathrm{ha}$ chemical fertilizer in strawberry production. For other crop production near Erhailake, including staple food, orchard, plants in recreation parks, fertilizer rates were much lower. In these regions, the ratios of $\mathrm{N}: \mathrm{P}_{2} \mathrm{O}_{5}: \mathrm{K}_{2} \mathrm{O}$ of composite fertilizers are mostly 11:11:11 and 17:17:17. If all producers used composite fertilizer with a ratio of 11:11:11, the rate of annually applied $\mathrm{P}$ to soil ranged from 7.3 to $435.5 \mathrm{~kg} \mathrm{P} / \mathrm{ha}$. In the case of 17:17:17, the rate ranged from 11.2 to $673.2 \mathrm{~kg} \mathrm{P} / \mathrm{ha}$.

Understanding which crop type uses the most fertilizer in which regions is an important first step to optimizing fertilizer rates, beginning discussions about where to apply nutrients, and when to apply and which type to apply. Conversations with producers determined that the higher rates can be attributed to the following: 1) These crops were produced multiple times per season; 2) For flower production, investment in building poly-houses and purchasing seedlings 
is high, thus the producers tend to adopt the "maintain and increase" method to eliminate the possibility of nutrient deficiency. Producers apparently neglected soil texture when determining application rates and rather decided rates based on land use and the selected crop types. Precise use of chemical fertilizers based on both crop type and soil properties seems to in a rudimentary stage in regions included in this research. In China, according to the statistics from Ministry of Agriculture, national application rates of chemical fertilizers per unit of land are about 2.5 times the amount applied in both the US and EU (http://www.moa.gov.cn/zwllm/tzgg/tz/201503/t20150318_4444765.htm).

\subsection{High P Concentration in Soils Is a Potential Pollutant Source to Water Bodies}

$\mathrm{NaOH}-\mathrm{P}$ concentrations were high in soils of regions near all lakes, according to criteria of Shangguan, et al. [17]. Even total P concentrations, which are typically higher than $\mathrm{NaOH}-\mathrm{P}$, are usually found to be less than $1000 \mathrm{mg} \mathrm{P} / \mathrm{kg}$ [18]. Our data show that the average values of layers in different regions ranged from 999 to $2094 \mathrm{mg} \mathrm{P} / \mathrm{kg}$ for $\mathrm{NaOH}-\mathrm{P}$ (Table 1), and for $\mathrm{NaHCO}_{3}-\mathrm{P}$ from 18.6 to $92.2 \mathrm{mg}$ $\mathrm{P} / \mathrm{kg}$. In China, generally, $20 \mathrm{mg} \mathrm{P} / \mathrm{kg} \mathrm{NaHCO}-\mathrm{P}$ in soils is considered as optimal for plant growth; and $40 \mathrm{mg} \mathrm{P} / \mathrm{kg}$ of $\mathrm{NaHCO}_{3}-\mathrm{P}$ as excessive for maximum growth of crops [19]. These levels of "readily available P" are clearly in excess of virtually all published sufficiency or optimal levels and suggest that with the possible exception of small amounts of starter $\mathrm{P}$, no further $\mathrm{P}$ fertilization is needed for nearly all crops. Some crops do not have published critical levels and thus further research is needed to obtain such levels.

A significant positive correlation between $\mathrm{NaOH}-\mathrm{P}$ and $\mathrm{NaHCO}_{3}-\mathrm{P}\left(y=0.69_{X}\right.$ $+3.52, \mathrm{P}<0.01)$ in all layers of soils near lakes reflects the dynamic relationship between reversibly-available $\mathrm{P}$ and readily-available $\mathrm{P}$, respectively (Guo et al. 2000). Fertilizer $P$ is usually quickly transformed into fractions of differing availability to plants according to soil sorption properties. Hence, high $\mathrm{P}$ input from massive fertilizer applications in regions surrounding these lakes will likely contribute to the buildup of the legacy P. The reversibly-available $\mathrm{NaOH}-\mathrm{P}$ in the $0-5 \mathrm{~cm}$ soil layer (Table 1) of soils in regions near these lakes ranged from about $1300-2100 \mathrm{mg} \mathrm{P} / \mathrm{kg}$ and has the potential to be a significant, long-term, non-point source of $\mathrm{P}$ pollution to the water bodies of lakes. Also of interest is the observation that Fuxianlake, which has some of the lowest levels of $\mathrm{P}$ in the lake water, also has some of the highest levels of $\mathrm{NaHCO}_{3}-\mathrm{P}$ and $\mathrm{NaOH}-\mathrm{P}$ in soils associated with the lake. The contrast may provide an opportunity to better understand factors that limit the loss of $\mathrm{P}$ from heavily fertilized soils to associated water bodies in this context.

\subsection{Production of Flower, Strawberry, Vegetable, Tobacco and Grapes as Critical Sources for Legacy P Buildup}

For flower, vegetable, grape, tobacco, and strawberry crops, $\mathrm{NaHCO}_{3}-\mathrm{P}$ and $\mathrm{NaOH}-\mathrm{P}$ concentrations were higher than in soils grown with staple food, plants 
Table 1. $\mathrm{NaHCO}_{3}-\mathrm{P}(\mathrm{mg} / \mathrm{kg}), \mathrm{NaOH}-\mathrm{P}(\mathrm{mg} / \mathrm{kg})$ concentrations in layer A $(0-5 \mathrm{~cm}), \mathrm{B}(5$ - $20 \mathrm{~cm}), \mathrm{C}(20-40 \mathrm{~cm})$, and CEC (cmole $/ \mathrm{kg}), \mathrm{pH}$, Sand\%, Silt\%, Clay\% and texture of soils in regions near lakes and Nanpan river.

\begin{tabular}{|c|c|c|c|c|c|c|c|c|c|c|}
\hline \multirow{2}{*}{$\mathrm{NaHCO}_{3}-\mathrm{P}(\mathrm{A})$} & \multicolumn{2}{|c|}{ Dianchi lake } & \multicolumn{2}{|c|}{ Erhai lake } & \multicolumn{2}{|c|}{$\begin{array}{c}\text { Fuxian and Xingyun } \\
\text { lakes }\end{array}$} & \multicolumn{2}{|c|}{ Nanpan river } & \multicolumn{2}{|c|}{ Yangzong lake } \\
\hline & 57.9 & $\mathrm{bc}$ & 53.2 & c & 63.2 & $\mathrm{~b}$ & 32.3 & $\mathrm{~d}$ & 92.2 & $\mathrm{a}$ \\
\hline $\mathrm{NaHCO}_{3}-\mathrm{P}(\mathrm{B})$ & 46.2 & $\mathrm{~b}$ & 41.6 & $\mathrm{~b}$ & 46 & $\mathrm{~b}$ & 36.1 & $\mathrm{~b}$ & 83.4 & $\mathrm{a}$ \\
\hline $\mathrm{NaHCO}_{3}-\mathrm{P}(\mathrm{C})$ & 28.2 & $\mathrm{~b}$ & 18.6 & c & 20.3 & c & 23.1 & $\mathrm{bc}$ & 49.1 & $\mathrm{a}$ \\
\hline $\mathrm{NaOH}-\mathrm{P}(\mathrm{A})$ & 1904 & $\mathrm{~b}$ & 1324 & c & 2094 & a & 1311 & $\mathrm{c}$ & 1847 & $\mathrm{~b}$ \\
\hline $\mathrm{NaOH}-\mathrm{P}(\mathrm{B})$ & 1634 & $\mathrm{~b}$ & 1244 & c & 1968 & a & 1430 & $\mathrm{bc}$ & 1726 & $\mathrm{ab}$ \\
\hline $\mathrm{NaOH}-\mathrm{P}(\mathrm{C})$ & 1332 & $\mathrm{~b}$ & 999 & c & 1541 & a & 1205 & $\mathrm{bc}$ & 1045 & c \\
\hline CEC & 20.7 & c & 12.3 & e & 15.9 & $\mathrm{~d}$ & 31.8 & $\mathrm{a}$ & 23.4 & $\mathrm{~b}$ \\
\hline $\mathrm{pH}$ & 6.8 & $\mathrm{~b}$ & 6.7 & $\mathrm{bc}$ & 7.2 & a & 6.4 & c & 5.6 & $\mathrm{~d}$ \\
\hline Sand & 22.9 & c & 35.8 & $\mathrm{a}$ & 29.1 & $\mathrm{~b}$ & 15 & $\mathrm{e}$ & 20.3 & $\mathrm{~d}$ \\
\hline Silt & 42.7 & $\mathrm{~b}$ & 49.4 & a & 42.1 & $\mathrm{~b}$ & 39.7 & $\mathrm{~b}$ & 35.9 & c \\
\hline Clay & 34.4 & $\mathrm{a}$ & 14.8 & c & 28.8 & $\mathrm{~b}$ & 45.3 & $\mathrm{a}$ & 43.9 & $\mathrm{a}$ \\
\hline Texture & \multicolumn{2}{|c|}{ Clay loam } & \multicolumn{2}{|c|}{ Loam } & \multicolumn{2}{|c|}{ Clay loam } & \multicolumn{2}{|c|}{ Clay } & \multicolumn{2}{|c|}{ Clay } \\
\hline
\end{tabular}

Means followed by same letters are not significantly different based on L.S.D. test across regions near lakes and the river $(\mathrm{P}<95 \%)$. Soil texture was categorized based on soil texture calculator (NRCS, USDA).

in recreation parks, and planted trees, particularly in the layer A $(0-5 \mathrm{~cm})$ of soil (Figure 2). Levels of $\mathrm{NaHCO}_{3}$-P significantly increased with larger fertilizer applications. This suggests that some proportion of soil $\mathrm{NaHCO}_{3}-\mathrm{P}$ was from fertilization, which contributed to P buildup. Unfortunately, the producers who cultivate grape did not reveal their fertilization rates, however particularly high $\mathrm{NaHCO}_{3}-\mathrm{P}$ levels in both the layers a $(0-5 \mathrm{~cm})$ and $\mathrm{B}(5-20 \mathrm{~cm})$ provides a strong suggestion that these crops also received excessive fertilizer applications. $\mathrm{NaHCO}_{3}-\mathrm{P}$ concentrations in the $5-20 \mathrm{~cm}$ soil layer, are critically important to plant growth. $\mathrm{NaHCO}_{3}-\mathrm{P}$ concentrations in both layer $\mathrm{A}$, the soil surface, and $\mathrm{B}$, the rooting zone, of soils cultivated with maize and rice in Erhai, Fuxian and Xingyun lakes also most likely exceed the needs of crops. For instance, in these regions, we found that $\mathrm{NaHCO}_{3}-\mathrm{P}$ concentrations (Table 2) were about $41 \mathrm{mg}$ $\mathrm{P} / \mathrm{kg}$ for maize (Zea mays) and $26 \mathrm{mg} \mathrm{P} / \mathrm{kg}$ for rice (Oryza sativa) in crop rooting zone $(5-20 \mathrm{~cm})$. Critical levels of $\mathrm{NaHCO}_{3}-\mathrm{P}$ for maize were $21.4 \mathrm{mg} \mathrm{P} / \mathrm{kg}$ and for rice $10.9 \mathrm{mg} \mathrm{P} / \mathrm{kg}$ in an investigation of soils of southwest, northeast, northwest and the central part of China [20].

$\mathrm{NaHCO}_{3}-\mathrm{P}$ concentrations in surface soils cultivated with flowers are in direct contact with runoff, and were very high (Figure 2). $\mathrm{NaHCO}_{3}-\mathrm{P}$ concentrations where flowers were grown such as Rosa sp., were, on the average, $97 \mathrm{mg} \mathrm{P} / \mathrm{kg}$ (Table 2), Dianthus sp.: $86 \mathrm{mg} \mathrm{P} / \mathrm{kg}$, Eustoma sp.: $116 \mathrm{mg} \mathrm{P} / \mathrm{kg}$. It is noteworthy that flowers such as Rosa sp. and Dianthus sp. are the most widely cultivated flowers in Yunnan province

(http://www.ynagri.gov.cn/news8305/20180306/6984101.shtml). Also of concern 
Table 2. $\mathrm{NaCO}_{3}-\mathrm{P}$ and $\mathrm{NaOH}-\mathrm{P}$ concentrations in soil layers $\mathrm{A}(0-5 \mathrm{~cm}), \mathrm{B}(5-20 \mathrm{~cm}), \mathrm{C}(20-40 \mathrm{~cm})$ under different crop types in regions near Dian lake, Fuxian and Xingyun lakes, Erhai lake, Nanpan river and Yangzong lake.

\begin{tabular}{|c|c|c|c|c|c|c|c|c|c|c|c|c|}
\hline \multirow{3}{*}{$\begin{array}{l}\text { Crop type } \\
\text { Strawberry }\end{array}$} & \multicolumn{6}{|c|}{$\mathrm{NaHCO}_{3}-\mathrm{P}(\mathrm{mg} / \mathrm{kg})$} & \multicolumn{6}{|c|}{$\mathrm{NaOH}-\mathrm{P}(\mathrm{mg} / \mathrm{kg})$} \\
\hline & \multicolumn{2}{|c|}{ Layer A } & \multicolumn{2}{|c|}{ Layer B } & \multicolumn{2}{|c|}{ Layer C } & \multicolumn{2}{|c|}{ Layer A } & \multicolumn{2}{|c|}{ Layer B } & \multicolumn{2}{|c|}{ Layer C } \\
\hline & 142 & $\mathrm{a}$ & 30 & defgh & 5 & $\mathrm{fg}$ & 1718 & bcdef & 965 & ef & 616 & fgh \\
\hline Grape & 124 & a & 66 & bcd & 21 & abcde & 1993 & bcde & 1564 & bcd & 1255 & cdef \\
\hline Garlic & 117 & a & 108 & a & 37 & $\mathrm{ab}$ & 1986 & bcde & 1985 & bcd & 1039 & defgh \\
\hline Eustoma & 116 & a & 107 & $\mathrm{ab}$ & 55 & a & 2868 & $\mathrm{ab}$ & 2702 & $\mathrm{ab}$ & 1793 & abcde \\
\hline Rosa & 97 & a & 68 & bcd & 35 & $\mathrm{ab}$ & 2325 & bcd & 1975 & bcd & 1547 & bcde \\
\hline Snap bean & 94 & $\mathrm{ab}$ & 57 & bcde & 17 & bcdef & 2297 & bcde & 2259 & abcd & 1683 & bcde \\
\hline Tomato & 88 & $a b c$ & 54 & bcde & 41 & $\mathrm{ab}$ & 2516 & $a b c$ & 2280 & $a b c$ & 2135 & $a b c$ \\
\hline Coriander & 87 & $a b c$ & 72 & $\mathrm{abcd}$ & 28 & $a b$ & 4148 & $\mathrm{a}$ & 4043 & a & 3575 & $\mathrm{a}$ \\
\hline Dianthus & 86 & $a b c$ & 67 & bcd & 24 & $\mathrm{abcd}$ & 1955 & bcde & 1782 & $\mathrm{bcd}$ & 1294 & cde \\
\hline Pepper & 82 & $a b c$ & 25 & efgh & 10 & cdefg & 2232 & bcde & 1845 & bcd & 1724 & bcde \\
\hline Myosotis & 81 & $\mathrm{abcd}$ & 75 & $\mathrm{abcd}$ & 32 & $a b$ & 1901 & bcde & 1980 & $\mathrm{bcd}$ & 1123 & cdefgh \\
\hline Gerbera & 74 & abcde & 30 & defgh & 9 & defg & 1309 & defg & 750 & ef & 518 & gh \\
\hline Broccoli & 72 & abcde & 49 & bcdef & 22 & abcde & 1549 & bcdefg & 1452 & bcde & 1076 & cdefgh \\
\hline Cymbidium & 64 & abcde & 36 & cdefg & 27 & $\mathrm{abcd}$ & 2473 & $\mathrm{abcd}$ & 2105 & bcd & 2081 & abcd \\
\hline Reed & 62 & abcde & 65 & bcd & 48 & $a b$ & 1566 & bcdefg & 1173 & cdef & 838 & efgh \\
\hline Dahlia & 58 & abcde & 83 & $a b c$ & 25 & abcd & 1186 & efgh & 1415 & bcde & 950 & efgh \\
\hline Loquat & 57 & abcde & 44 & cdef & 39 & $\mathrm{ab}$ & 2400 & bcd & 2171 & abcd & 2131 & $a b c$ \\
\hline Maize & 52 & bcde & 41 & cdef & 19 & bcde & 1417 & cdefg & 1291 & cde & 1112 & cdefgh \\
\hline Taro & 52 & bcde & 59 & bcd & 26 & $\mathrm{abcd}$ & 1293 & efg & 1340 & cde & 992 & efgh \\
\hline Sun flower & 51 & bcde & 36 & defg & 20 & bcde & 1639 & bcdef & 1530 & bcd & 1364 & bcde \\
\hline Pear & 43 & bcdef & 41 & cdef & 27 & $a b c$ & 870 & fgh & 762 & ef & 975 & efgh \\
\hline Tobacco & 43 & cdef & 44 & cdef & 18 & bcde & 1293 & efg & 1257 & cde & 993 & efgh \\
\hline Gypsophila & 43 & cdef & 43 & cdef & 35 & $\mathrm{ab}$ & 1393 & cdefg & 1525 & $\mathrm{bcd}$ & 1396 & bcde \\
\hline Marigold & 40 & cdef & 39 & cdefg & 22 & abcde & 1485 & bcdefg & 1518 & bcde & 1222 & cdefg \\
\hline Herbaceous perennials & 39 & def & 35 & defg & 30 & $\mathrm{ab}$ & 2459 & bcd & 2161 & bcd & 2162 & $\mathrm{ab}$ \\
\hline Redsage & 31 & efg & 13 & hi & 4 & $\mathrm{~g}$ & 1133 & efgh & 1035 & cdef & 860 & efgh \\
\hline Rice & 26 & fg & 18 & gh & 10 & defg & 1020 & fgh & 987 & ef & 941 & efgh \\
\hline Crape myrtle & 24 & fgh & 21 & fgh & 16 & bcdef & 776 & gh & 1018 & def & 884 & efgh \\
\hline Lavender & 20 & fgh & 21 & fgh & 16 & bcdef & 1654 & bcdef & 1486 & bcde & 1081 & cdefgh \\
\hline Bush & 17 & gh & 15 & hi & 18 & bcde & 1312 & defg & 1333 & cde & 1215 & cdefg \\
\hline Pine & 15 & gh & 23 & efgh & 24 & abcde & 1541 & bcdefg & 887 & ef & 816 & efgh \\
\hline Poplar & 11 & $\mathrm{~h}$ & 7 & $\mathrm{i}$ & 7 & efg & 568 & $\mathrm{~h}$ & 578 & $\mathrm{f}$ & 463 & $\mathrm{~h}$ \\
\hline
\end{tabular}

Means followed by same letter are not significantly different based on L.S.D test, $\mathrm{P}<0.05$. 
are the vineyards, which are widely distributed in regions around Erhailake. $\mathrm{NaHCO}_{3}-\mathrm{P}$ concentrations in surface soils (layer A) cultivated with grapes were $124 \mathrm{mg} \cdot \mathrm{P} / \mathrm{kg}$. Understanding the critical level of $\mathrm{P}$ for each crop and soil condition, above which the crop yield does not increase with additional $\mathrm{P}$ fertilizer applications, is important for nutrient management, as this is one way to help reduce the potential $\mathrm{P}$ loss and increase fertilizer use efficiency [21]. Unfortunately, there are few estimates of critical levels of $\mathrm{NaHCO}_{3}-\mathrm{P}$ for garlic, grape and several of the flower species above mentioned. Nonetheless, these high levels of $\mathrm{NaHCO}_{3}-\mathrm{P}$ in surface $(0-5 \mathrm{~cm})$ soils should be a cause for concern for further pollution of these water bodies.

$\mathrm{NaHCO}_{3}-\mathrm{P}$ concentrations in surface soils (layer A) cultivated vegetables were also high, especially with garlic. On the average, $\mathrm{NaHCO}_{3}-\mathrm{P}$ in surface soils cultivated with garlic was $117 \mathrm{mg} \mathrm{P} / \mathrm{kg}$, with snap bean, $94 \mathrm{mg} \mathrm{P} / \mathrm{kg}$, with tomato, $88 \mathrm{mg} \mathrm{P} / \mathrm{kg}$, and coriander, $87 \mathrm{mg} \mathrm{P} / \mathrm{kg}$ (Table 2). Garlic, in recent years, has been a profitable crop for local producers and is cultivated on a large scale in the province [22]. These high levels of $\mathrm{P}$ in the surface soil are likely contributing $\mathrm{P}$ to runoff, except in the case of Fuxian lake mentioned above.

Notably in layer $\mathrm{C}$ of soils, soils used for production of flower, vineyard, vegetable and tobacco contained higher $\mathrm{NaOH}-\mathrm{P}$ and $\mathrm{NaHCO}_{3}-\mathrm{P}$ than where other crops were grown (Figure 2). This suggests that significant $\mathrm{P}$ leached or moved into deep layers of soils and contributed to a buildup of $\mathrm{P}$, which poses long term nutrient management concerns since high levels could be a source of $\mathrm{P}$ loading to the underground water. In a research comparing greenhouse vegetable production with 13-year massive input of $\mathrm{P}$ with 1-year production, it was found that total $\mathrm{P}$ in soils $(0-20 \mathrm{~cm})$ under long-term $\mathrm{P}$ input increased 4 fold [23].

It is evident that $\mathrm{P}$ leached to deeper soil levels in flowers and vegetable cropping systems. This leaching seems evident because $\mathrm{NaHCO}_{3}-\mathrm{P}$ values were higher (Figure 2) in layer B $(5-20 \mathrm{~cm})$ of soils used for production of flowers and vegetables than other crops. It may be that fewer nutrients leached to layer $\mathrm{C}$, however low $\mathrm{NaHCO}_{3}-\mathrm{P}$ may have resulted from either less leaching to that layer or that the nutrients were leached deeper than layer $\mathrm{C}$.

\subsection{Strategies to Reduce Excessive Fertilization and High Levels of Soil P}

In general, soils in recreational parks in regions near Dianchi lake contained much lower $\mathrm{NaHCO}_{3}-\mathrm{P}$; however, $\mathrm{NaOH}-\mathrm{P}$ concentrations were almost as high as with soils cultivated with flowers. This indicates that build-up of recreational parks with plants that receive less fertilization would be a possible long-term remediation to reduce $\mathrm{P}$ loading. The easiest recommendation to make, but the hardest communicate to farmers, is to use less fertilizer, however additional guidance regarding timing, type and application would also reduce impacts on lake water quality. Guidance on what amounts, type, when, and where fertilizers are applied are important suggestions that can help inform producers on how to 
reduce potential to pollute and reduce cost of fertilizer while maintaining crop productivity and quality [24]. This research suggests that prioritizing flower, vegetable and grape production systems might be the most effective in reducing overall $\mathrm{P}$ concentrations in the surrounding lakes that originate from agriculture. However, there is currently insufficient information on local optimal fertilizer management strategies of these crops. There is a clear need for on-farm field experiments with these crops to better guide fertilizer recommendations.

Soil properties that can help inform fertilizer management: Another way to help producers reduce excess fertilizer use is to create awareness of soil properties and their relationship to fertilizer uptake by plants. For instance, Figure 3 shows that for Erhailake, there are spatial differences in soil texture and CEC that can be translated into recommended fertilization management for producers with additional field experiments. Soils with higher CEC and clay fraction have higher $\mathrm{P}$ retention and water-holding capacity and thus subject less nutrient to leaching [25]. In soils in regions to the west of Erhai lake, nutrients are more likely to be lost through surface runoff and leaching, because soils in these regions contain low clay and CEC, and the agricultural land is mostly of low-slope in the west of the Erhai basin [26]. Therefore, for these soils it is recommended that fertilization be managed to reduce pollution potential. Possible management options include more frequent fertilizer additions with smaller amounts to increase nutrient use efficiency, changes in application depth and timing, and inclusion of retention basins to catch sediments that are entrained in surface runoff as water exits the farm plot.

In regions surrounding Fuxian and Xingyun lakes, the soil was slightly alkaline (Table 1). In regions surrounding Dianchi and Erhai lake, near Nanpanriver, however, the soil was slightly acidic. Farther east, to Yangzong lake, the soil was mildly acidic. Soil CEC was higher in soils near Nanpan river followed by Yangzong lake, Dianchi lake, Fuxian and Xingyun lakes, and Erhai lake. In regions surrounding Dianchi lake, soils consisted, on the average, 23\% sand, $43 \%$ silt, and $34 \%$ clay, which is categorized as clay loam (Table 1 ). In regions surrounding Erhai lake, soils, on the average, consisted of 36\% sand, 50\% silt, and $15 \%$ clay, which is categorized as loam. In regions surrounding Fuxian lake and Xingyun lakes, soil, on average, consisted of $29 \%$ sand, $42 \%$ silt, $29 \%$ clay, which is categorized as clay loam. In Southwest of the province, near Yangzong lake, soils, on average, consisted of $20 \%$ sand, $36 \%$ silt, and $44 \%$ clay. The soil of the farm near Nanpanriver, on average, consisted of only $15 \%$ sand, $40 \%$ silt, $45 \%$ clay, which is categorized as clay textured soil.

There is an urgent need to reduce excess fertilization in sandy soils with low CEC (such as Erhai lake), because the low buffering capacity of these soils can predispose soil $\mathrm{pH}$ to significant decrease under long-term massive use of chemical, especially ammoniacal fertilizers [27]. Low levels of clay and, consequently high levels of sand, are also important factors reducing P sorption and increasing leachability. 


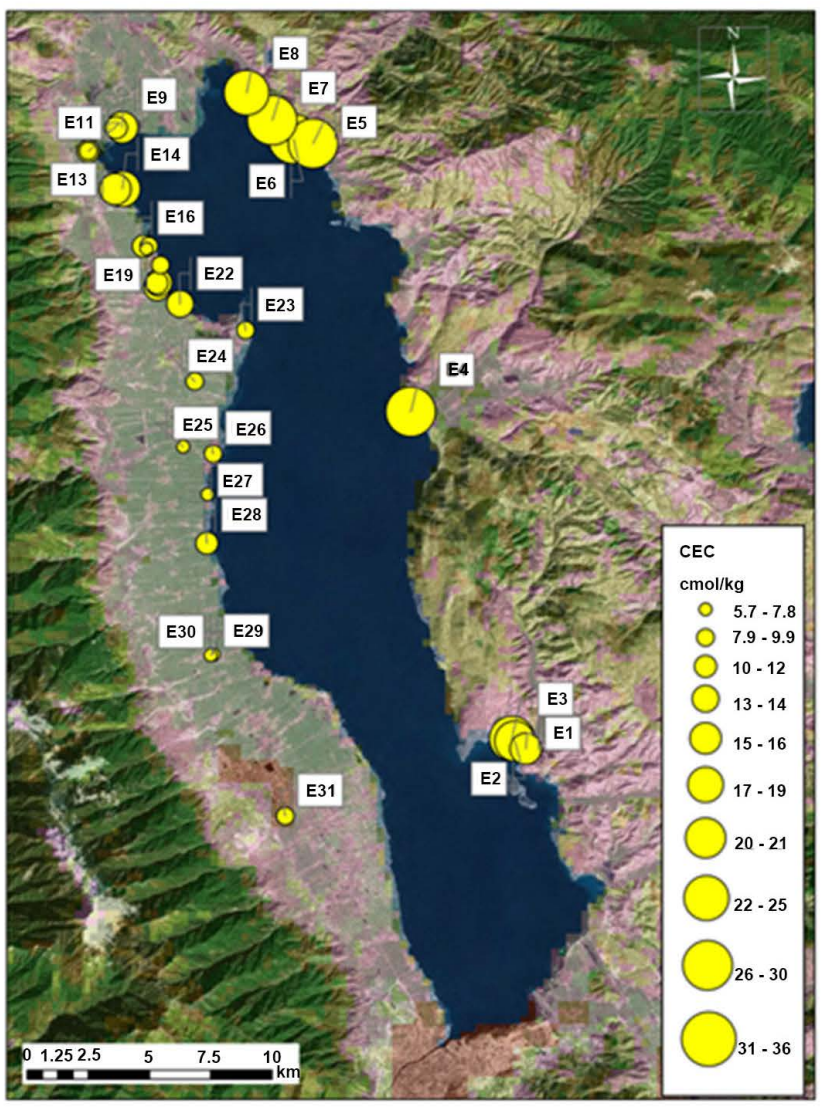

(a)

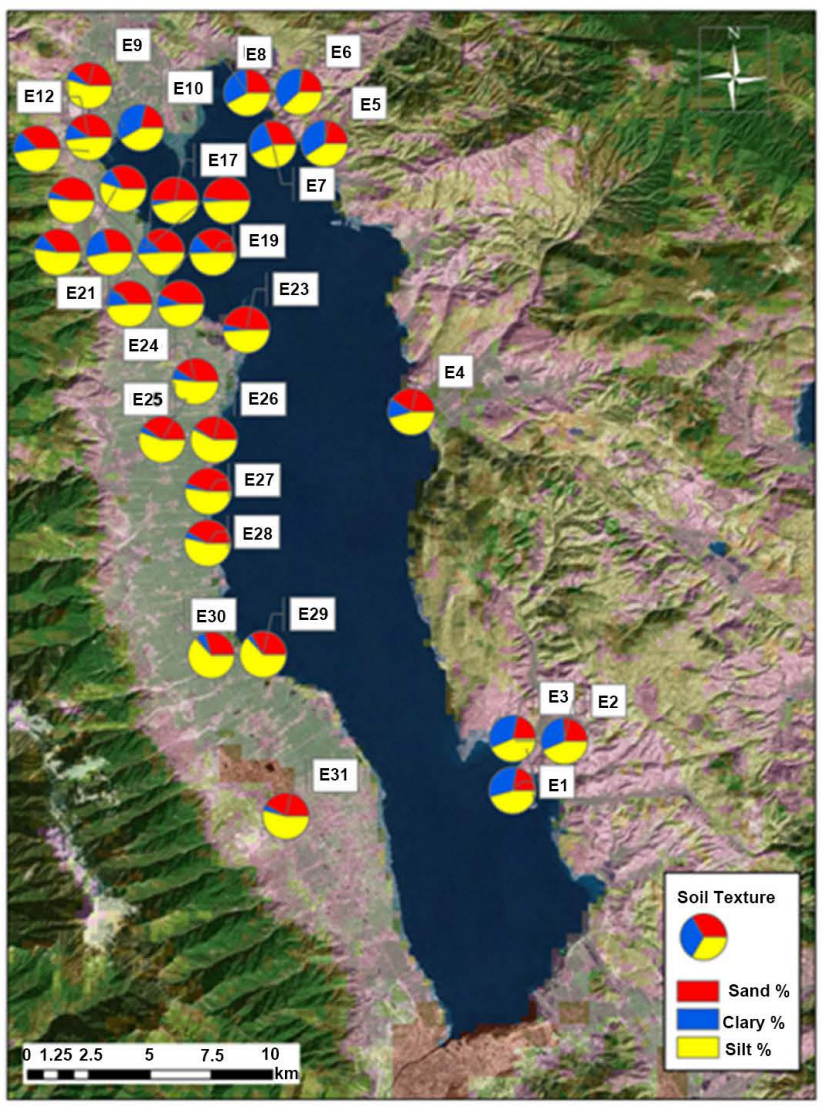

(b)

Figure 3. (a), (b). CEC, Sand\%, Silt\% and Clay\% in soils surrounding Erhai lake. Area highlighted with pink color is arable land.

In contrast, soils surrounding Dianchi, Fuxian and Xingyun lakes might be more weathered than soils surrounding Erhai lake, because soils in regions around Dianchi, Fuxian and Xingyun lakes contained significantly higher NaOH-P (Table 1), which is often associated with more highly weathered soils with high sorption capacity [28]. Combined with higher buffering capacity because of higher clay and CEC, in the short term, fertilization management alone is not sufficient to reduce the high $\mathrm{P}$ in surface $(0-5 \mathrm{~cm})$ soils around Dianchi, Fuxian and Xingyun lakes to a level below which $\mathrm{P}$ is not considered as a driving factor of loading and eutrophication. Therefore, a portfolio of best management practices (BMPs) is needed to trap excessive sediment-bound $\mathrm{P}$ in regions surrounding these lakes in the near future.

Early research on $\mathrm{pH}$ of the water in Fuxian and Xingyun lakes revealed that $\mathrm{pH}$ ranged from $8.5-9.1$, and that $\mathrm{Na}^{+}, \mathrm{K}^{+}, \mathrm{Ca}^{2+}, \mathrm{Mg}^{2+}$ make up about $50 \%$ of total cations in water samples. This area contains large amounts of limestone and dolomite probably accounting for high $\mathrm{pH}$ in the water [29]. Soils surrounding Fuxian and Xingyun lakes might be more alkaline because of long-time irrigation with water of such high $\mathrm{pH}$ and basic cation content.

\section{Conclusion}

In the current study, our data reveal a significant association of annual fertilizer 
application rates (AFAR) with specific crops in regions surrounding four important lakes, namely, Dianchi, Erhai, Fuxian and Xingyun lakes, in Yunnan province, China. Fertilizer application rates to flowers, grape, strawberry and vegetables were much higher than that applied to other crops. Soil properties, an important factor affecting fertilizer nutrient retention and release, could be used to determine appropriate fertilizer rates, but apparently such factors were not considered when producers selected fertilizer application rates. Although tobacco producers did not reveal application rates, high $\mathrm{NaHCO}_{3}-\mathrm{P}$ and $\mathrm{NaOH}-\mathrm{P}$ levels in all 3 layers $(0-5 \mathrm{~cm}, 5-20 \mathrm{~cm}$, and $20-40 \mathrm{~cm})$ of tobacco soils were similar to those where high levels of fertilizers were applied in the production of flowers, grapes, strawberry, tobacco and vegetables. This association also suggests that current fertilization rates might exceed that necessary for these crops. Excessive fertilizer application rates appear to be a critical factor contributing to the buildup of legacy $\mathrm{P}$ in soil layers, particularly the surface $0-5 \mathrm{~cm}$ layer, which likely contributes to $\mathrm{P}$ pollution to water bodies of lakes. Soil texture, $\mathrm{pH}$, and CEC of soils surrounding these lakes varied significantly, suggesting when additional fertilizer $\mathrm{P}$ is needed, fertilizer application rates should be adjusted depending on soil properties. The high levels of both readily available $\mathrm{P}$ and the reversibly available $\mathrm{P}$ indicate that appropriate BMPs, tailored to reducing runoff and removing nutrients from runoff, should be established to trap excessive $\mathrm{P}$ before it reaches the lakes.

\section{Acknowledgements}

The authors acknowledge assistance and support of Zhiguo Yang, Axiang Zhao, and Tansheng Miao. Dr. Zou and Dr. Falinski contributed equally to this manuscript.

\section{Funding Information}

This study was funded by Yunnan leading talent funding (2016HA005) and funding of Department of Yunnan science and technology (2016ZA006).

\section{Conflicts of Interest}

The authors declare that they have no conflict of interest.

\section{References}

[1] Bennett, E.M., Carpenter, S.R. and Caraco, N.F. (2001) Human Impact on Erodable Phosphorus and Eutrophication: A global Perspective. BioScience, 51, 227-234. https://doi.org/10.1641/0006-3568(2001)051[0227:HIOEPA]2.0.CO;2

[2] Keatley, B.E., Bennett, E.M., Macdonald, G.K., Taranu, Z.E. and Gregoryeaves, I. (2011) Land-Use Legacies Are Important Determinants of Lake Eutrophication in the Anthropocene. PLOS ONE, 6, e15913. https://doi.org/10.1371/journal.pone.0015913

[3] Filippelli, G.M. (2008) The Global Phosphorus Cycle: Past, Present, and Future. Elements, 4, 89-95. https://doi.org/10.2113/GSELEMENTS.4.2.89 
[4] Gao, W., Howarth, R.W., Swaney, D.P., Hong, B. and Guo, H.C. (2015) Enhanced N Input to Lake Dianchi Basin from 1980 to 2010: Drivers and Consequences. Science of the Total Environment, 505, 376-384. https://doi.org/10.1016/j.scitotenv.2014.10.016

[5] Huang, D.-B., Bader, H.-P., Scheidegger, R., Schertenleib, R. and Gujer, W. (2007) Confronting Limitations: New Solutions Required for Urban Water Management in Kunming City. Journal of Environmental Management, 84, 49-61. https://doi.org/10.1016/j.jenvman.2006.05.004

[6] Xie, J., Wu, D.-Y., Chen, X.C., Kong, H.N., Xiao-Ying, P.U., Yang, X.X., et al. (2013) Relationship between Aquatic Vegetation and Water Quality in Littoral Zones of Lake Dianchi and Lake Erhai. Environmental Science \& Technology, 36, 55-59.

[7] Sharpley, A., Jarvie, H.P., Buda, A., May, L., Spears, B. and Kleinman, P. (2013) Phosphorus Legacy: Overcoming the Effects of Past Management Practices to Mitigate Future Water Quality Impairment. Journal of Environmental Quality, 42, 1308-1326. https://doi.org/10.2134/jeq2013.03.0098

[8] Guo, F. and Yost, R.S. (1998) Partitioning Soil Phosphorus into Three Discrete Pools of Differing Availability. Soil Science, 163, 822-833.

https://doi.org/10.1097/00010694-199810000-00006

[9] Guo, F., Yost, R.S., Hue, N.V., Evensen, C.I. and Silva, J.A. (2000) Changes in Phosphorus Fractions in Soils under Intensive Plant Growth. Soil Science Society of America Journal, 64, 1681-1689. https://doi.org/10.2136/sssaj2000.6451681x

[10] He, L.B., Bi, J. and Zhao, Y. (2012) A Survey on Agricultural Cultivation in the Typical River Basins of Dianchi Lake Catchment. Environmental Science Survey, 31, 38-41.

[11] Cheng, L., Yin, C., Hu, W. and Zhou, Y. (2010) Subsidy Policy for Agricultural Nonpoint Pollution Control in Northern Area of Erhai Lake of Yunnan Province. Research of Agricultural Modernization, 31, 471-474.

[12] Pizzeghello, D., Berti, A., Nardi, S. and Morari F. (2011) Phosphorus Forms and P-Sorption Properties in Three Alkaline Soils after Long-Term Mineral and Manure Applications in North-Eastern Italy. Agriculture, Ecosystems \& Environment, 141, 58-66. https://doi.org/10.1016/j.agee.2011.02.011

[13] Hedley, M., Stewart, J. and Chauhan, B. (1982) Changes in Inorganic and Organic Soil Phosphorus Fractions Induced by Cultivation Practices and by Laboratory Incubations. Soil Science Society of America, 46, 970-976. https://doi.org/10.2136/sssaj1982.03615995004600050017x

[14] Watanabe, F.S. and Olsen, S.R. (1965) Test of an Ascorbic Acid Method for Determining Phosphorus in Water and NaHCO3 Extracts from Soill. Soil Science Society of America Journal, 29, 677-678. https://doi.org/10.2136/sssaj1965.03615995002900060025x

[15] Page, A.L. (1965) Methods of Soil Analysis. Part 2. Chemical and Microbiological Properties. American Society of Agronomy Inc., Soil Science Society of America Inc., Madison, WI.

[16] Dane, J.H. and Hopmans, J.W. (2002) Methods of Soil Analysis: Part 4 Physical Methods. SSSA Book Series 5.4, SSSA, Madison.

[17] Shangguan, W., Dai, Y., Liu, B., Zhu, A., Duan, Q., Wu, L., et al. (2013) A China Data Set of Soil Properties for Land Surface Modeling. Journal of Advances in Modeling Earth Systems, 5, 212-224. https://doi.org/10.1002/jame.20026

[18] Delgado, A. and Scalenghe, R. (2010) Aspects of Phosphorus Transfer from Soils in 
Europe. Journal of Plant Nutrition and Soil Science (Zeitschrift fuer Pflanzenernaehrung und Bodenkunde), 171, 552-575. https://doi.org/10.1002/jpln.200625052

[19] Zhong, X., Zhao, X., Bao, H., Li, H., Li, G., and Lin, Q. (2004) The Evaluation of Phosphorus Leaching Risk of 23 Chinese Soils I. Leaching Criterion. Acta Ecologica Sinica, 24, 2275-2280.

[20] Bai, Z., Li, H., Yang, X., Zhou, B., Shi, X., Wang, B., et al. (2013) The Critical Soil P Levels for Crop Yield, Soil Fertility and Environmental Safety in Different Soil Types. Plant \& Soil, 372, 39. https://doi.org/10.1007/s11104-013-1800-3

[21] Mcdowell, R.W. and Sharpley, A.N. (2004) Variation of Phosphorus Leached from Pennsylvanian Soils Amended with Manures, Composts or Inorganic Fertilizer. Agriculture Ecosystems \& Environment, 102, 17-27. https://doi.org/10.1016/j.agee.2003.07.002

[22] Li, X., Deng, B.T. and Hua, Y.E. (2011) The Research Based on the 3-R Principle of Agro-circular Economy Model-The Erhai Lake Basin as an Example. Energy Procedia, 5, 1399-1404. https://doi.org/10.1016/j.egypro.2011.03.242

[23] Fei, L., Zhao, M., Chen, X. and Shi, Y. (2011) Effects of Phosphorus Accumulation in Soil with the Utilization Ages of the Vegetable Greenhouses in the Suburb of Shenyang. Procedia Environmental Sciences, 8, 16-20.

https://doi.org/10.1016/j.proenv.2011.10.005

[24] Ohnston, A.M. and Bruulsema, T.W. (2014) 4R Nutrient Stewardship for Improved Nutrient Use Efficiency. Procedia Engineering, 83, 365-370.

https://doi.org/10.1016/j.proeng.2014.09.029

[25] Gaines, T.P. and Gaines, S.T. (1994) Soil Texture Effect on Nitrate Leaching in Soil Percolates. Communications in Soil Science \& Plant Analysis, 25, 2561-2570. https://doi.org/10.1080/00103629409369207

[26] Yang, L., Wang, Z.Q., Jin, G., Chen, D.D. and Wang, Z. (2015) Geological Risk Assessment for the Rapid Development Area of the Erhai Basin. Physics and Chemistry of the Earth, 90, 79-90.

[27] Thomas, G.W., Sparks, D.L., Page, A.L., Helmke, P.A., Loeppert, R.H., Soltanpour, P.N., et al. (1996) Soil pH and Soil Acidity. In: Sparks D Methods of Soil Analysis. Part II, Soil Science Society of America, Madison, WI, 1159.

[28] Cross, A.F. and Schlesinger, W.H. (1995) A Literature Review and Evaluation of the Hedley Fractionation: Applications to the Biogeochemical Cycle of Soil Phosphorus in Natural Ecosystems. Geoderma, 64, 197-214. https://doi.org/10.1016/0016-7061(94)00023-4

[29] Zhu, Y. (1994) Factors Influencing pH in Water Body of Three Lakes in Yuxi Area. Environmental Science Survey, 15-19. (In Chinese) 